\title{
Komunikat NSZZ Solidarność KWB Bełchatów
}

\author{
Statement of the Solidarity Union \\ in Brown Coal Mine Bełchatów
}

Abstract

The statement concerns the threats to the functioning of the company resulting from the government restructuring program of the Polish power industry.

Keywords - Solidarity Union, Brown Coal Mine Betchatón, restructuring program, Polish power industry 


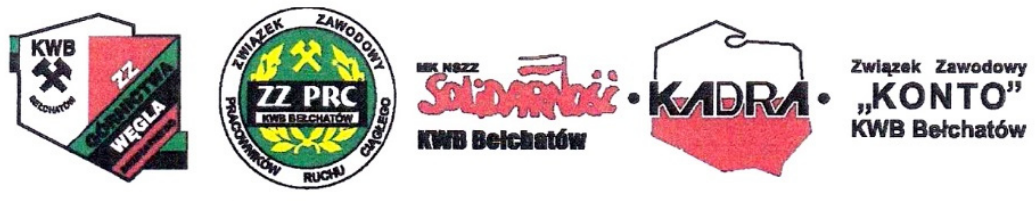

Rogowiec, dn. 08.05.2020 r.

\section{KOMUNIKAT}

Już dziś widoczne są skutki pandemii - załamanie gospodarki, zmniejszenie zużycia energii i uwidocznienie zapaści w służbie zdrowia. Koszty powrotu do normalności będą liczone w miliardach i nie nastąpi to tak szybko, jak tego zapewne oczekujemy.

Dlatego z całą bezwzględnością musimy spojrzeć „wirusowi” prosto w oczy i powiedzieć - nic już nie będzie takie samo, jak przed pandemią. Idą bardzo ciężkie czasy dla gospodarki polskiej, a więc także dla Kopalni i Spółek zależnych. Prawdopodobnie główny ciężar działalności związkowej będziemy musieli skoncentrować nie na walce o wynegocjowanie nowych praw, lecz na walce o zachowanie już nabytych.

Musimy pamiętać o tym, że od 1998 roku 5 związków zawodowych negocjowało i podpisywało co kilka lat nowe umowy gwarancyjne zapewniające pracownikom kopalni trwałość stosunku pracy, pewność obowiązywania Zakładowego Układu Zbiorowego Pracy, Zakładowego Funduszu Świadczeń Socjalnych, Pracowniczych Programów Emerytalnych (w tym BOLERO) oraz ubezpieczeń medycznych. Aktualna umowa gwarancyjna obowiązuje do 31 grudnia 2027 roku.

Na wzór obowiązujący w Kopalni, od 2016 roku gwarancje zatrudnienia obejmują również pracowników spółek zależnych, tj. Betransu, Bestgumu, Rambu i Megserwisu. I tutaj składamy deklarację, że jako strony porozumień dotyczących gwarancji zatrudnienia będziemy bronić naszych członków i ich miejsc pracy. Dodatkowo w Spółkach Betrans, Bestgum i Ramb obowiązuje porozumienie zawarte w 2014 r. gwarantujące coroczne podwyżki płac.

Na ten niewątpliwy sukces składa się praca nie tylko związów zawodowych, ale przede wszystkim pracowników Kopalni oraz Spółek, dających nam wsparcie w kluczowych momentach. Bez Waszego zaangażowania sami moglibyśmy zdziałać zdecydowanie mniej. Niestety, tak jak napisaliśmy wcześniej, dla Kopalni i Spółek zależnych nadciągają ciężkie czasy.

\section{Zwracamy uwage na 3 najbardziej aktualne zagrożenia:}

1. Wskutek ogromnej opieszałości a zarazem bezradności Rządu RP istnieje coraz mniejsza szansa na budowę Odkrywki Złoczew, co w konsekwencji bardzo skraca perspektywę pracy w KWB Bełchatów i drastycznie ogranicza działalność Spółek zależnych. Już dziś musimy podjąć działania przygotowawcze do funkcjonowania poza datą 31.12.2027; do takich działań menadżerskich potrzebna jest odpowiedzialna, odważna i kreatywna dyrekcja Kopalni oraz Zarządy Spółek zależnych.

Pomimo obietnic składanych przez niektórych polityków nie widać realnej szansy na budowę odkrywki Złoczew, podobnie jak na dalsze finansowanie GKS-u Bełchatów. 
Niestety, dopiero w czasie próby widać, ile są warte obietnice niektórych posłów oraz wspierających ich działaczy związkowych.

2. Poziom etatyzacji w KWB Bełchatów i Spółkach zależnych. Już w III kwartale br. powinniśmy przystąpić do negocjacji związanych z ustaleniem poziomu etatyzacji w latach następnych. Nie musimy nikomu przypominać, jak wygladał nabór do pracy w poprzednich latach. Wielokrotnie zatrudniano pracowników nie tam, gdzie były największe niedobory i na zawyżone stawki osobistego zaszeregowania. Oby rządzący PGE GiEK S.A. zdecydowali się na bardziej racjonalne i zgodne z wewnętrznymi aktami zasady rekrutacji, chociaż $w$ świetle polityki personalnej prowadzonej w centrali spółki trudno o optymizm.

3. Dramatyczna i chaotyczna wymiana kadr w PGE GiEK S.A., co niezbyt dobrze rokuje na przyszłość tej Spółki, a tym samym także nas, pracowników Kopalni i Spółek zależnych. Jeszcze trochę kontynuacji takiej atmosfery i nie będzie komu podejmować jakichkolwiek decyzji, nie mówiąc już o tych kluczowych dla naszego dalszego istnienia.

Jeżeli nie zostanie podjęta prze Rząd RP decyzja o budowie odkrywki Złoczew, oby nie, to jakie działania osłonowe wobec załogi Kopalni i Spółek zależnych podejmie zarząd PGE oraz PGE GiEK S.A.? Już dziś musimy rozpoczać rozmowy o przyszłości kompleksu energetycznego w Bełchatowie i zatrudnionych tu kilkunastu tysiącach pracowników. Nikt, nawet aktualny Rząd, nie jest w stanie zagwarantować pracy dla wielotysięcznei rzeszy ludzi zlokalizowanych w bełchatowskim zagłębiu energetycznym.

Bez zaangażowania władz centralnych możemy co najwyżej liczyć na powtórke losu Wałbrzycha oraz Tarnobrzega, a tego chcemy przecież uniknać!

Drodzy pracownicy Kopalni i Spółek zależnych! Jako związkowcom zawsze leżało nam na sercu dobro i przyszłość naszych zakładów pracy; zdajemy sobie jednak sprawę z tego, że każde zasoby, a więc także i węgiel brunatny, mają swój naturalny koniec eksploatacji. I do tego bezpiecznego końca eksploatacji musimy się dobrze, odpowiedzialnie przygotować. Nie możemy w tym liczyć na pomoc polityków, którzy myślą jedynie w kadencyjnym cyklu czteroletnim i boją się powiedzieć coś niepopularnego, mogącego wpłynąć na wysokość słupków społecznego poparcia.

Dlatego sami mụsimy wziąć sprawy w swoje ręce i ponownie zawalczyć o przyszłość naszych załóg. Dosyć kłamstw, czas na prawdę, nawet tę bolesną!
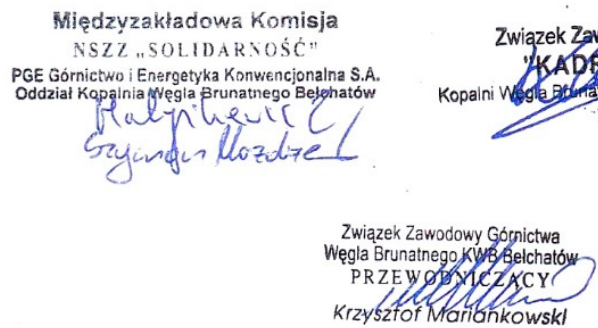

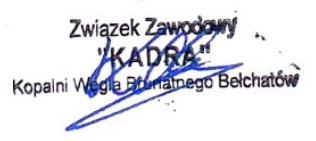

ZWIAZEK ZAWODOWY

PRACOWNIKÓW RUCHU CIAG KWB BEKCHATÓW

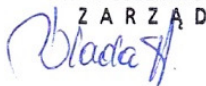

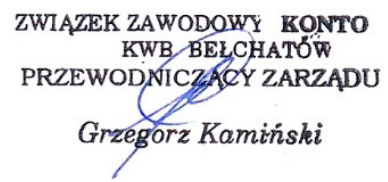

